\title{
Introduction to the pioneers and the issues
}

\section{William G. Shepherd and Henry W. de Jong}

\section{INTRODUCTION}

This book is about pioneers, the scholars who have created the economics field known as 'industrial organization' (it has also been called 'industrial economics' in Britain and Europe). The field's core is about: (i) competition, the driving force of most modern markets, and (ii) monopoly power, which interferes with competition's good results.

The field also has a public-policy side. The pioneers have analyzed the policies which try to prevent monopoly, or to cure or restrain monopoly once it exists. The policies have mainly included: antitrust, to prevent or reduce monopoly power; regulation to restrain 'natural monopolies'; deregulation, which removes restraints, in the hope that competition will take over; and public enterprise, which aims to provide various public interests when competition will not work.

The field dates from the 1870 s, and it has been worldwide in scope. Its best-known pioneers since the 1870s have worked in Europe, Britain, the United States and Canada. Americans have developed much of the field's technical content since about 1900. But some early British and European innovations began before that, and many others continued during the twentieth century. They too are presented here.

Although the subject has ancient roots, the modern research innovations began primarily in the 1880 s and 1890 s, when basic concepts were invented as the new 'neoclassical' microeconomic theory rapidly emerged. The pioneering was also driven by turbulence in many real industries, where mergers, anti-competitive actions, and new technology were creating industrial monopolies.

In response to that, American antitrust and regulation policies were also being created, as ways for the public to prevent or to control the rising monopoly problems. These antimonopoly efforts created spectacular dramas in the US during 1900 to 1920. Antitrust officials hit most of the very biggest companies with lawsuits, and new regulatory commissions began to set limits on powerful new electric and telephone monopolies. In contrast, European and British governments in the 1920s encouraged a massive spread of cartels, which fixed prices and rigged markets in most industries.

In the 1930s the field began a more 'modern' phase, with new technical ideas, and there have been many more changes in the decades since then. Some of the new ideas have led to great progress, while others have ranged down to modest value or little at all, or even backward steps and detours. All of the innovations have stirred sharp debate, and most of the new ideas have aimed to increase competition.

As we have developed this book, we have had to create our own format and methods,

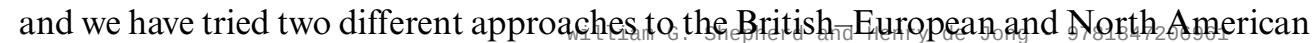


parts. We hope that the whole book conveys the excitement of the field, as well as its unusually broad and diverse content.

\section{Brilliant Writing about Brilliant Pioneers}

We present those pioneers here, explaining and assessing their innovations. The main share of the writing has been done by a group of fine writers in Europe and North America, drawing on their deep scholarship and familiarity with the field's modern growth.

In the introductory section that follows in this chapter, we review the main lines and periods of innovation in the entire global field. Then in the Part I, we turn to Britain and Europe. First there is an introduction, and then a review of the earlier, larger trends during 1200-1800. Next come six chapters on major countries: German-language areas, the Low Countries, France, Italy, Britain and Scandinavia. There are also nine individual profiles on important pioneers.

Then comes Part II, which covers North America. First there is an introduction to the field's development in the United States and Canada. It mentions the 43 leading pioneers, and it also briefly summarizes some 51 other innovators. Then follows the individual profiles on those 43 prominent North American pioneers.

Our coverage is meant to be concise and readable, perhaps even enjoyable, and not overly detailed. We focus on the main innovations, rather than on the entire lives and careers of the innovators.

\section{Controversy is Pervasive}

Have no illusions: this field is both important and quite contentious. Capitalism's main driving force - the competitive process - attracts intense emotions and arguments about what is fair, who is really the most creative or efficient, which players should get rich (or shouldn't), and how society itself is shaped. Large blocs of corporate power and momentous industrial policies have taken form in Europe, Britain, the US and around the globe. Many blocs have had sharp effects, often for many decades.

The field's findings about such deep and spectacular events are often controversial. The conflicting points of view can create high tensions, and the evidence about the blocs and their impacts is rarely conclusive. Further, the cleft between pure theory and applied realworld research has deepened since about 1970. Theories are often disputed sharply, on both small and large points, and the scholars' debates often shift directions quickly.

Moreover, the companies involved in the issues have often worked ruthlessly to win the debates and their own legal cases, and to bend national policies their own way. They have often tried to marshall scholars as their friendly spokesmen and favorable expert witnesses.

We try to show how - even amid these pressures - the scholarly innovators have used new concepts and methods to study competition and monopoly, both in the many real markets 'out there' and also in purer realms of lonely thought and collegial seminars. Also, the pioneering scholars have often helped to develop and weigh the policies (antitrust and regulation, as well as laissez-faire) that ${ }_{\text {might }}$ get the $_{\text {thest }}$ marketeresults. 9781847206961 
The pioneers shown in this book are actually few, compared to the many thousands of scholars who have tilled the field since the 1870s. Many of those others have labored productively, but with less impact on the field's ideas.

For each North American pioneer, we aim to focus on the original contributions, with just enough personal details to set the context and give life to the person. Each writeup is therefore much more concise than would be a rounded biographical review of the scholar's whole life and works. For example, none of the North American pioneers is given as much as 10 printed pages, even though some major innovators would merit a book of their own.

Our task here requires care, long experience in the field, technical skill, and a sense of caution, not to mention humility. We have consulted widely among colleagues about which pioneers have been important and why. We have sought consensus, but ultimately this book reflects our best judgments about people, issues and the evolving shape of the industrial organization field. Each of us brings a half-century of scholarly experience to this book, and we have actually known most of the pioneers personally.

The next part of this chapter gives a road-map to the changing ideas and debates. We note the field's very early history, and we explain and interpret the shape of the more modern field as it grew after the 1870s and again after 1930 . We note that some supposedly 'new' ideas have actually been introduced long before, as often happens in many scholarly fields. We place the pioneers in context, and we discuss the importance of the innovations within the whole field.

\section{WHO IS INCLUDED, AND WHY}

But first, we explain here this book's criteria and methods; why the various pioneers were included, and how the book is designed.

\section{Criteria for Including Pioneers}

In 2002, Mark Blaug invited Shepherd to prepare a comprehensive book on 'pioneers in industrial organization', to be issued by Edward Elgar Publishing. Shepherd accepted with enthusiasm, but also with a sense of great caution. Enthusiasm, because the field is exciting, important, and packed with fateful issues. Caution, because any presentation of pioneers is bound to touch on touchy debates and contrasting views.

Shepherd has frequently asked Blaug and Elgar's editors for guidance in designing the book, especially: what whole period to cover, what methods are best for choosing pioneers, whether to write individual profiles or national chapters, and many other matters of form and method. No such guidance was given. All dimensions of the book were left entirely to the author.

Shepherd soon realized he would need to find a co-author to cover the Europe-andBritain side, and he was exceedingly fortunate to secure Henry W. de Jong for that task. The choice was obvious. An erudite scholar who also sets high and precise standards, de Jong has long been a prolific and reigning research expert in the Netherlands and Europe - as well as Shepherd's close friend and colleague epherd and Henry de Jong - 9781847206961 
With a free hand from Edward Elgar Publishing, we have taken great care in defining what 'pioneers' should mean, setting the time coverage, designing the book's format, deciding which types of details to include, and every other dimension. So we have had to develop our own definitions and designs, while seeking much advice from our colleagues.

The pioneering in this field has involved research both into the nature and facts of markets, and into the public policies that might be best. The research pioneering may enlarge the specific concepts, the underlying research methods, or the information about real conditions in real markets. Each of those categories has involved a large variety, with important changes as the decades have passed. An innovation may also involve the content, specific choices, or methodology of policies, such as antitrust or regulation. Each of those policies, too, has contained much variety and change over the decades; think of strict versus lenient periods of antitrust, and of regulation (1920s-1960s) versus deregulation (from 1975 on).

A pioneer does not just explore, but rather - in the ideal case - creates order, a new system, and new research capacity. To use homely metaphors, a pioneer does not just explore a wilderness, but mainly clears the underbrush, sets boundaries, makes fields to plow, and builds roads, houses and whole farms. That is, pioneers add new research ways to define reality, to measure its conditions, and to interpret the issues.

The new capacity can be new concepts which come from pure deductions using abstract theory, or instead come from more practical ideas based on inductive thinking and experience. Pioneering can involve doing the first work on a new or neglected topic, on a new set of information, on a little-known sector of the economy, or on a novel idea for policy devices or methods. The pioneers' new research capacity can also create new evidence, by adding facts or by showing how to process data - and interpret the results - in more effective ways.

A few truly protean pioneers have gone on and on, providing decades of substantial innovations which have lasted well. The other innovators have scaled down by gradations of importance, and some have made just one or two brief additions to narrow points. Some have stayed in this field, while others have moved on to other subjects.

\section{'New' Ideas Can Have Great Value, or Merely Modest Worth, or Even Reduce Understanding}

As in every field, mere novelty in itself is not enough. Some 'innovations' are actually dead ends, which inject 'new' ideas and methods that unfortunately turn out to be neither fruitful nor lasting. The resulting detours and false leads can displace good ideas, rather than genuinely improve the field's content.

A common reason for dubious innovations is the universal dynamic of 'the career'. Young scholars often advance their careers by publishing whatever 'new' and 'seminal' ideas they can think up, while disparaging the existing ideas as 'obsolete' or 'not rigorous'. This activity may often yield real progress, but it may instead replace sound knowledge and research methods with false leads.

Genuine pioneers are those who really enhance the field, adding superior ideas and evidence without crowding out effective and important ideas. The judgments about these true innovations can be debatable. Robust debate and sifting $_{n}$ qut the superior $_{4}$ competing 
ideas is what 'the literature' is supposed to achieve. But the literature's debating process can be distorted or confused or led astray, at least for a while. Sometimes, many years or even decades of debate are needed to evaluate 'new' ideas and methods properly.

\section{Time Coverage: Mainly from the 1870s to the Mid-1980s}

We could have begun with the 1930s, when the 'modern' twentieth-century analysis of oligopoly began in a blaze of excited theorizing. To some colleagues, those 1930s seem ancient, at 70 years ago. A number of young scholars since the 1970s are even more sure that 'new is best'. They have scorned all pre-1970s ideas, brushing off the 1930s-1960s as dim and shallow. As for the pre-1930s period, that is a hopeless Stone Age. Only the "new IO theory' since 1970 is true pioneering.

But that view is, to put it mildly, ignorant and wrong. There was major pioneering from the 1870s on. The European field has deep roots in even earlier centuries, as de Jong and his authors explain in Part I. And on both sides of the Atlantic Ocean, major innovations were made in the 1880s and 1890s, when this field was being formed. Many of the supposedly 'new' ideas in the post-1950s literature were actually debated brilliantly and extensively well before 1910. In the US, the post-Civil War booms and rising market warfare involved massive new problems: competition of many kinds, monopoly and dominance, scale economies, mergers, collusion, tactical price discrimination, 'predatory pricing', the blocking of entry, utility pricing, and other classic market actions. All these had already put the most important market concepts into dramatic industrial practice. And that sparked intensive discussion, often with great analytical clarity, practical knowledge and wisdom. ${ }^{1}$

'Newness' has often been over-claimed by scholars, especially since the 1950s. A review of 'modern pioneers' requires us to recognize the earlier true pioneers. Some scholars since the 1920s have said they were 'pioneering', but they were in faux jungles that had been explored, clarified and tamed long before. Later scholars have often added refinements and nuances, but the really large innovations since the 1930s have been much less than their advocates have claimed.

So the beginnings of pioneering go back at least to the 1870s; what is the suitable endpoint for our coverage in this book? Today, yesterday, the year 2000, the 1980s? After debating the choices and consulting with many others, we have ended the main coverage in the mid-1980s, at about 1985 . $^{2}$ That makes sense, because the ideas and trends since 1985 are still too new, open to question, and ripe for revision. Trying to include all the recent new research thoughts and claims would be premature. There will be time enough later to recognize the best ones, perhaps in a new pioneers book.

\section{How Many Pioneers?}

Pioneers might seem to be a very few protean giants. But this field has had many important innovators; over 40 from North America are given individual profiles here, and over 50 more less-prominent innovators are noted. There is also a wide range of European and British pioneers. Perhaps these numbers may seem high to some of our readers, but there are many causes at work. 
The field is uncommonly wide and inclusive, and it is unusually diverse and rich in its differing research methods. Those methods range from pure theory (including mathematical modeling) and applied theory, all the way over to factual studies of many kinds on many topics and scores of major industries. There is also a wide array of publicpolicy instruments (antitrust, regulation, deregulation and public enterprise), all subject to hot debates and big changes since the 1880s. Shepherd's 'Introduction' below (to the North American pioneers), lists no fewer than 16 important topic areas in this field, and each of them contains further specialized subjects.

Moreover, the research and real-world conditions have stretched over many countries, including the US, Britain, those in Europe, Japan, Australia and others. The time period extends well over 100 years, and it contains several distinct eras. The innovations have been quite numerous, and there have been rapid changes in topics, styles, methods, fact sources and economic sectors. The sectors alone show dramatic shifts. They began with industrial metals and railroads and the telephone and electric utilities during 1860-1900, to automobiles, chemicals, plastics and medicines during 1900-1950, then to computers, communications and space technology during 1950-1970, and now to internet-related markets, genetic manipulation and nanotechnology. There have been many contending ideas, and the research field has not moved smoothly toward concise, universally-accepted truths. Progress has often been choppy, even chaotic, and given to hot debates.

\section{Economists Only}

This book is about economists, creating economic ideas. It is true that some other types, including lawyers, have sometimes influenced economists and the field. ${ }^{3}$ But the correct professional focus is on genuine economic pioneers who were professionally trained in economics, engaged in the methods and the refereed research literature of economics, and were under the sustained discipline of professional economic criticism.

\section{The Sequence}

This field is very wide-ranging, and moreover the timing of ideas sometimes is complicated. Some pioneers contributed numerous ideas over several decades, not just once or twice. Many pioneers cannot be neatly assigned to a short time-period or even to a specific decade. So a coherent account of those pioneers needs to extend over their pioneering activities, to reach a rounded assessment of everything they did.

Most North American pioneers are placed at the time when their innovations began taking hold. That involves some judgment on our part. The North American pioneers are grouped into a single broad category, which embraces research into markets and theory, as well as policies including antitrust, regulation and deregulation.

\section{Varying Lengths of Profiles for Varying Pioneering Contributions}

A few pioneers have had fundamental effects, or have worked on a variety of topic areas over several decades, while others have ranged down to creative but highly specialized work during a brief period. Relying on much consultation and advice from colleagues, we have tried to fit the write-ups to the wioneers' noles andimportance, The main method 
is to vary the number of pages: more for big innovations, fewer for the lesser ones. A uniform length would not fit the true range of pioneering.

In Britain and Europe, some leading pioneers are given specific coverage in 'profiles'. In the North American coverage, the pioneers' relative importance is suggested partly by the length of the profile. Our authors did not stick rigidly to the suggested page lengths we gave them. Some came in a little short, or a little long, as economists often do. But the lengths here do suggest the relative importance. Colleagues and other readers will, of course, reach their own judgments about these matters of relative importance.

As for the book's whole length and the depth of detail, our estimable publisher was willing to provide up to 500 printed pages for the book's length. But we and our authors have worked to make it more concise and clear, with brevity to appeal to a wider readership.

\section{Disagreements and Schools, Amid Corporate Pressures}

The field has always been tumultuous. New methods and data have frequently come in abrupt shifts, or irregular waves, some with wide agreement but others with acerbic debates. And mathematics and pure theory versus applied research have bred fractious debates for over a century. Even personality can matter; some facile scholars with outsized personalities have often rattled the field - at least for a while - more than their cautious and understated colleagues.

Some of the pioneers have written mainly about their own contributions, but some other scholars have rebuked others' research and methods for being 'obsolete', while praising their own for 'rigor' and power. When ideas and scholars have been mobilized directly on opposite sides of important policy cases, the arguments can grow rough. ${ }^{4}$ The field's literature is itself supposed to function as a high-class debating society, to thrash out correct judgments among such claims, some of them quiet, others loud. But a successful sifting is not guaranteed. We have sought a fair balance among these diverse contending views, amid the frequent overstatements.

\section{Available Authors}

The coverage here has also been affected by our access to first-rate colleagues who were both interested and available to write these contributions when we invited them. Securing the authors has been a challenge, as they say, amid the high pressures of modern research and the attractions of expert-witness work. Both de Jong and Shepherd have chosen to write some of the profiles, but they have also filled in by writing others when authors were scarce.

\section{What's in the Write-ups}

For Europe, one scholar deals with each country. Although standard formats were suggested, the authors have followed their own judgments in dealing with matters of content.

For the North American innovators, the authors were asked to provide the standard personal basic facts about the pioneers: birth and,death dates and places, theireducational 
degrees, their main professional positions, and other details where relevant. On the main innovations themselves, the authors were asked to describe them and their importance, their effects on the field, any debates about their nature, and a summary of where the contributions stand now. At the end of each profile, we asked for a listing of the main publications where the innovations were presented.

\section{HOW THE FIELD’S MAIN TOPICS HAVE EVOLVED}

Now we turn from this book's design to matters of intellectual history. We present a review of the field's main issues. We review briefly the background and emergence of the whole field, and then its main shifts from the 1870s to 1985.

\section{Background}

The most basic and ancient questions in this field have been: what moves the market to its actual prices, and are those prices acceptable to the market's participants and to society? These questions go back at least to the century beginning in 1200, far before the modern era. A brief summary of those early issues will give depth to this book.

Scholastic price theory developed in Europe after 1200 to assess whether prices are acceptable or too high, and if government-set prices would be better for the public good. These questions are still central: how can we explain the prices in the market, and how are the outcomes valued (value being the balance of advantages and disadvantages to all the parties)? In those early times, the goods were basic foodstuffs, land and natural resources, labor, money and other liquid capital. Now of course they also include a vast array of advanced products and services.

But the issues are still much the same. Monopoly pricing could come in many ways; by individuals who raised prices by the famous engrossing, forestalling and regrating, or by using still other illicit agreements, secret pacts or conspiracies. Or various actions by guilds or other groupings could also fix prices or set minimum prices. Against that, the free-market process (then often called 'common estimation'; the term competition did not yet exist) might give the benefits of moving prices down toward costs, or at least mediating between surpluses and deficits.

In those early times, schools developed. An example is the Parisian school (1200-1350), which was almost unanimously in favor of free-market pricing and opposed to monopoly. The majority in this school favored competition (or 'common estimation'). But a few, for example, Henri van Ghent (writing about 1280), would allow entrepreneurs some influence, in an embryonic Schumpeterian idea. Even so, all in the Parisian school would accept government pricing or related constraints, if the common good required it.

By the 1700s, Adam Smith and Anne Robert Jacques Turgot were seeing competition as the basis for achieving the public good. They opposed all forms of monopolizing control and did not mention any entrepreneurial contribution. By contrast, Richard Cantillon held that entrepreneurs set markets in motion. On the whole, continental theory followed Cantillon, while the Anglo-Saxon British view fitted Smith (though with exceptions).

Smith's 'invisible hand' did not make valuations, which instead are done by persons or institutions. If the market's outcome is avalued as negative on balance, ${ }_{80}$ then its ${ }_{1}$ rules 
or structures can be changed. This continental view is seen in the nineteenth century and later, with Friedrich von Wieser and Robert Liefmann, who were German-area economists in the 1920s and 1930s. It accorded with the closed markets of the time. Since the Second World War, world markets have opened and integrated across borders, and the strong rise of competition rules in the European Union have applied pressure on the individual governments.

\section{Many 'new' ideas are actually familiar and 'old'}

By the 1870 s, evidently, some basic ideas had already been debated and clarified down the centuries. As debate continued further, many more basic issues were illuminated by the 1920s. Some later 'new' ideas were actually superfluous. Some pioneers merely selected among the various known ideas, to refine and rename one or two of them.

At each moment, the field is not a sum of all previous innovative ideas. Many 'new' ideas have little merit and usually they do not get accepted at all. Others have some play but are soon whittled down to a modest role, or they may be displaced entirely. Sometimes a new idea will replace one or several of the 'established' concepts. So the pioneers' contributions have had a variety of fates; some still retain importance now; many others have faded, and some are entirely gone; others have faded and then regained importance. So you should bear in mind that ideas come and go as debates proceed.

The early concepts were pretty simple, as seen from today's technical varieties, but they were basic and powerful. Later innovations had varied importance. Fundamental ideas were installed rapidly during $1870-1910$, even though the mail was slow by today's internet standards. Ideas might take years to emerge among the few scholars in the elite academic campuses (as with Augustin Cournot in Europe and Charles Ellet in the US). Some early ideas seemed just to materialize, rather than to appear from one scholar's paper at one precise moment.

Computers and the internet have sped things greatly, but the human brain is still the source where new ideas emerge and are judged, and it remains both fertile and fallible, and judgments often take a long time to gel. The best thinkers in this field still take care and time to assess innovations, and debates can proceed for many years.

\section{The field's main ideas, and the problem of causation}

As we noted at the start, the core of the field has been about competition and monopoly, and how they affect markets and the whole economy. The modern field has divided into several main subtopics:

1. Degrees of competition and monopoly How much competition or monopoly power is there in a given market? Market structure is often important in this.

2. Determinants of competition or monopoly What determines the degree of competition? Technology, and the economies and diseconomies of scale, are important in this.

3. Behavior How do competition and monopoly affect firms' behavior? Pricing and other strategies are important, by one dominant firm or by several oligopolists.

4. Performance How are profits, prices, efficiency, innovation and other elements of performance affected by the degree of competition and monopoly power? 
Underlying these subtopics is the fundamental question of causation: which way does causation run, from competitive structure forward to behavior and performance? Or is it the reverse: from a firm's performance back to shape its market position? Mainstream scholars have urged the first view. Competition (or monopoly power) in a market shapes the behavior and performance of firms in that market; usually, competition yields excellence, while monopoly harms performance (raising prices and reducing innovation). When markets have imperfections, firms can capture monopoly power and exert it harmfully.

An opposite view urged by free-market advocates is that firms can gain market power only if they truly earn it, by being genuinely more efficient and innovative. For that to be so, markets would need to be essentially perfect. Free-market advocates do assume that markets are perfect, and so they argue for the reverse causation: performance shapes structure and behavior. Strong monopoly occurs rarely, they say. When monopoly does occur, it is actually good rather than harmful. And it will not last unless government interferes to protect it.

This question of cause and effect may seem arcane and dry, but it is quite fundamental. The debate has been intense and divisive from the start - and particularly since the 1960s. Your belief about causation affects whether you believe that monopoly usually causes trouble (the mainstream view) or usually is beneficial and welcome (by free-market doctrine). Our pioneers have recognized these opposed possibilities. Some have had neutral attitudes toward the answers, while others have lined up firmly on one side or the other.

These four subtopics further divide into many specific topics, involving concepts and measurement. Those detailed points are presented in Chapter 9, introducing the North American pioneers.

\section{The Beginnings}

The basic ideas have been familiar since earliest civilized times, and we have noted how the 1200s brought scholastic analysis. Competition induces extra efforts and, sometimes, creativity. Firms that can exert control over markets will raise their prices and restrain output, aiming to gain riches. They will also take anti-competitive actions to entrench their power. Richard Cantillon and Adam Smith noted both these points, and installed the consumers' choices in the market, among many or even a few competing suppliers, as the anchor of efficient economic systems.

During the next 100 years, from the 1770 s to the 1870 s, a few further concepts were added. Johann Heinrich von Thünen united thoughts deriving from Smith's dynamic equilibrium economics with Continental emphasis on entrepreneurial moves. However, his message, which stressed the productivity growth as the main solution to the 'social problem', got lost in the move towards neo-classical static analysis. Some politicians used crude Manchester school 'competitive markets' ideas to excuse the widespread social harms of the new industrial capitalism. But a specialized research field did not develop. Cournot wrote about duopoly in the 1830s, but his work was noted only decades later. Ellet in the US also developed sophisticated early ideas abut pricing, but he too gained little notice at the time.

But when neo-classical theory burst forth in the 1870 s, perfect competition - and its practical variations - began to be analyzed in $_{\text {sidetail }}{ }_{\text {an }}$ Competitive outcomes $_{6}$ became 
defined as a set of precise technical conditions of equilibrium costs and prices. Monopoly's conditions and impacts were also studied, in theory and fact.

Real industrial events reinforced the urgency of research during these formative 1880-1900 decades. The spokesmen for big business claimed that new economies of scale made necessary a rising flood of mergers and dominant firms, which threatened to eliminate competition in hundreds of markets. That pressured the handful of rising scholars to think and write in detail about the field's central topics. They also were driven to debate the need for policies like antitrust and the regulation of utilities.

By 1900 most of the big, permanent topics - market imperfections, anti-competitive abuses that created dominant firms, the harms of monopolies as well as their possible benefits, economies of scale and 'natural monopolies', price collusion and discrimination, innovation - all of these had been faced and debated, often clearly and wisely. Monopoly's damages were known, but neo-liberal free-market advocates had also arisen to defend monopoly, both in Europe and Britain and in the US.

Looked at broadly, by 1900 the field ranged from pure theory to highly-applied research, along with an intense exposure to many important real industries. Applied research was the field's mainstream activity.

\section{Leading Innovations During the Twentieth Century}

It is helpful now to survey briefly the main series of topics that arose during the whole twentieth century. Next, the European chapters, and then the North American coverage, will fill in the details about the pioneers and their specific innovations.

\section{0-1920}

Research activity was moderately active in Europe, as some scholars moved beyond neoclassical theory to study practical features of competition. But there was little research on policies against monopoly, either in industry or utilities.

In contrast, US research was deeply involved in antitrust policies and new regulation of the nascent utility monopolies. ${ }^{6}$ Decisive rulings were made against price fixing (the 1899 Addyston Pipe case) and single-firm dominance (the Standard Oil, American Tobacco and AT\&T cases, among others). But actual 'trust-busting' was moderate, and early regulation fitted careful and sound economics.

\section{The 1920s}

The 1920s brought forth fewer new ideas in both Europe and the US. Amid depression in Europe, policies there retreated into a widespread encouragement of cartels in thousands of industries. In the US, both antitrust and regulation receded. ${ }^{7}$

\section{The 1930s}

European thinking still focused on cartels, but in the US this decade erupted with major innovations, amid the stresses of the Great Depression. The control within large US corporations was rethought, and oligopoly theory rapidly emerged in 1932-33, displacing single-firm dominance as the leading topic. Other pioneering included an index of monopoly, kinked demand curves, the nature of the firm, and the studies of major new datasets on industrial concentration 
involved vertical integration and controls, natural monopolies, economies of scale, and the structure-behavior-performance triad.

\section{The 1940s}

The US debates intensified further, and they brought in new concepts. Joseph Schumpeter defended large firms for being engines of innovation, yet the antitrust attacks on major firms actually increased. Game theory was created, and the mathematizing of theory took hold. Yet a wave of industry studies also brought new practical research into oligopolies.

\section{The 1950s}

Now began a rich era for research and policy, in both North America and Europe. In Europe the 1950s began with French innovations of marginal-cost pricing for electric utilities, soon joined by British economists and policies. By 1956 there were also strong new research and policy moves against the thousands of entrenched cartels, toward installing pro-competitive laws and agencies to reduce monopoly in the new European Union as well as in individual countries.

US scholars developed new methods for defining markets, and these were soon used in leading antitrust cases. New concepts included 'countervailing power', the possible benefits of price discrimination, barriers against new competition, and 'engineering estimates' and the 'survivor technique' for measuring the economies of scale. Meanwhile free-market defenses of market power were increasingly asserted. And though this was a golden era for regulation, early critiques of it were emerging. ${ }^{8}$

\section{The 1960s}

This decade was also highly innovative, and methods grew even more diverse and the debates grew even more active. In Europe and Britain, research deepened into competitive conditions and the economies of scale. Also, the antitrust policies toward dominance, mergers and price fixing were strengthened and refined. Public enterprises in coal, electricity and telephones improved their pricing and efficiency, especially in France and the UK.

In the US, new computers enabled large-scale econometric research, covering many conditions: industrial concentration, entry barriers, prices and profit rates, advertising, innovation, discrimination in employment, and wages. The concepts and facts of innovation were studied in unusual depth. There was both much variety and a broad balance among many research methods.

The economic rigor of US antitrust policies was raised, while the Supreme Court applied tight criteria to mergers and pricing. New critiques alleged that utility regulation caused inefficiency and excess investment. There were rising calls for deregulation, especially in financial markets, the transportation industries (airlines, railroads and trucking), and telephone service.

In parallel with neo-liberal critics in the UK and Europe, free-market critics at Chicago, Los Angeles and Rochester increasingly attacked all public policies. They asserted that markets were virtually perfect, so that public actions could only distort economic efficiency. 


\section{The 1970s}

European and UK research developed further, especially on the economies of scale and on mergers. In 1979, Britain began to privatize nearly all public enterprises and to remove public regulations to constrain monopoly power. This created many unregulated private monopolies, but new competition often failed to develop.

In the US, research proliferated and diverged even more into real-world and puretheory styles. The decade began with two landmark monograph-textbooks: by F.M. Scherer on mainstream research, and by A.E. Kahn on utility regulation and possible competition. The 1970s also brought more econometric analysis of monopoly and performance, individual dominant firms, profitability, innovation, mergers, wages, and discrimination by race and gender. Mergers and economies of scale also both received intensive study, as also did transactions costs. Areeda and Turner in 1975 urged testing for 'predatory pricing' by using marginal costs, and this was quickly accepted by many colleagues and the courts.

In parallel, pure theory also spread rapidly. Called 'new IO theory' by its advocates, abstract modeling became popular, especially using game theory. Free-market theorists asserted an 'efficient-structure' hypothesis, though with little research basis. Major US antitrust cases challenged AT\&T's telephone monopoly and IBM's dominance of computers. Deregulation spread to many sectors in the US, especially financial markets, airlines and railroads.

\section{The early 1980s}

European research advanced on many levels in the early 1980s, and pro-competitive policies in the UK and Europe became comparable or even stronger than US policies. Europeans joined cautiously in the rising US focus on game theory and mathematical models.

In the US, game theory's popularity rose to a peak, and a theory of 'contestable markets' was announced. After 1980, the Reagan Administration cut US antitrust policies deeply and inserted 'new IO theory' to replace the evidence about market definition and concentration. They also pressed deregulation into more sectors.

$$
* \quad * \quad * \quad *
$$

These summary points are a framework for the individual innovators and details that follow. First come the Europeans and British pioneers, and then the North Americans. We do not imply relative importance or leadership by this sequence. Various Europeans and British pioneers contributed before 1900, but the North American scholars soon made large innovations in both research and policies. European governments eased back, treating monopoly and collusion much more tolerantly until the 1950s, and they quietly relegated much of the utility-monopoly problems (pricing, efficiency and innovation) to public firms.

The most important European pioneering came later, beginning in the 1950s. And as US policies came to be dominated by free-market advocates and theorists after 1970, European policies to promote and protect competition actually became stronger and more consistent with the mainstream. 


\section{NOTES}

1. Examples include: 'predatory pricing' by Standard Oil in the 1870 s, the 'survivor technique' idea by John Stuart Mill before 1860, Alfred Marshall and the 'evolution' of firms in 1890, and John Bates Clark's discussion of entry barriers in 1887.

2. It is true that a few of our writers have taken the liberty to discuss a few of their pioneers' post-1980s developments. Some of those later works often relate closely to their pre-1985 innovations.

3. Active lawyers have included Thurman Arnold, A.A. Berle and Walton Hamilton in the 1930s and 1940s, Aaron Director in the 1950s, and Robert H. Bork and Richard A. Posner from the 1960s on. The legal scholar Donald F. Turner may seem to be an exception from the 1950s-1970s, but he held an economics PhD from Harvard and much of his work met strict refereed-journal standards.

In some degree of contrast, the Chicago school led by George Stigler and its journals (especially the Journal of Political Economy and the Journal of Law and Economics) often gave easy acceptance to papers from its like-minded group of legal writers, including Bork and Posner.

4. For example, many leading scholars were drawn into the huge US antitrust cases toward IBM and AT\&T in the 1970s, and the Microsoft cases in the 1990s and early 2000s.

5. See Almarin Phillips and Rodney E. Stevenson, 'The historical development of industrial organization', History of Political Economy, Fall 1974, pp. 324-42.

6. William Letwin, Law and Economic Policy in America (Random House, New York, 1965); Hans B. Thorelli, The Federal Antitrust Policy (University of Chicago Press, Chicago, 1954); Walton Hamilton and Irene Till, Antitrust in Action, vol. 16, Temporary National Economic Committee, Washington, DC, US, Government Printing Office, 1940; Philip Areeda and Donald F. Turner, Antitrust Law, 7 vols (Little, Brown, Boston, MA 1978).

7. Though an exception was John M. Clark's Studies in the Economics of Overhead Costs in 1923.

8. Including Walter Adams and Horace Gray's Monopoly in America: The Government as Promoter (Macmillan, London, 1955, and the 1959 attack on railroad regulation by John Meyer, Merton Peck, John Stenason and Charles Zwick, Competition and the Transportation Industries of the United States (Harvard University Press, Cambridge, MA). 